\title{
Fool me once... treatment exposure to achieve remission in pediatric IBD
}

\author{
Johan E. Van Limbergen ${ }^{1}$ - Bart G. P. Koot ${ }^{1}$ • J. Peter de Winter ${ }^{2,3}$ \\ Published online: 2 November 2020 \\ (C) Springer-Verlag GmbH Germany, part of Springer Nature 2020
}

New guidelines on the treatment of Crohn's disease in children from the European Crohn's and Colitis Organisation (ECCO) and the European Society of Pediatric Gastroenterology, Hepatology and Nutrition (ESPGHAN) have recently been published [1]. With the notable exception of dietary studies, most of the evidence base for our current management of pediatric inflammatory bowel disease (IBD) is rooted in adult trials with pediatric modifications following dose-finding or observational studies [2].

Placebo-controlled trials in pediatric IBD are rare and only considered ethical in a limited set of circumstances such as studying add-on medication to already proven effective therapy and where placebo-controlled trials have not previously been conducted in adults $[2,3]$. As a consequence, adult data together with real-life experience cohorts are for a large part the shaky evidence to position interventions in the treatment algorithm of pediatric IBD.

In this issue of the European Journal of Pediatrics, two studies in real-life experience cohorts are published. Scarpato et al. compare the effects of exclusive enteral nutrition (EEN) versus corticosteroids as remission therapy on several shortand long-term outcomes in 68 children with Crohn's disease using historical data (2003-2013) from their center [4]. Jongsma et al. report in their multicenter retrospective observational study on the dose of infliximab prescribed to young ( $<10$ years) versus older children ( $>10$ years) with IBD and

Johan E. Van Limbergen

j.e.vanlimbergen@amsterdamumc.nl

1 Dept of Pediatric Gastroenterology and Nutrition, Emma Children's Hospital, Amsterdam University Medical Centers, AMC, Amsterdam, The Netherlands

2 Department of Pediatrics, Spaarne Gasthuis, Hoofddorp, Haarlem, The Netherlands

3 Department of Development and Regeneration, KU Leuven, Leuven, Belgium its association with therapeutic drug levels, treatment response, and the development of antibodies to infliximab [5].

Besides providing data on optimizing remission therapy in children with IBD with all the limitations that accompany retrospective data collection, more can be learnt from these studies. The two studies published in this issue also illustrate the importance of not being fooled repeatedly by considering merely absence of symptoms, i.e., an elevated clinical disease activity index, as sufficient. Successful induction (with normalization of inflammatory markers as a proxy measure for intestinal mucosal healing) is necessary before embarking on maintenance therapy. These studies challenge us to revisit induction dosing strategies based on the re-interpretation of adult studies for pediatric care $[4,5]$. A key figure to highlight in this context is that rates of steroid-free remission in adult trials are typically $20 \%$ lower than reported rates of clinical remission [6].

For children with IBD achieving sustained steroid-free remission is incredibly essential. The use of steroids varies greatly between centers and countries and is often more representative of local expertise and bias than based on evidence $[1,7,8]$. The common theme of these retrospective studies by Scarpato et al. [4] and Jongsma et al. [5] being how much "treatment exposure" matters: equally for the positive outcomes of mucosal healing and clinical remission as for the adverse effects of steroid-dependence, loss of response, and primary non-response.

With comparable rates of early clinical remission to steroids, nutrition (exclusively or partial enteral nutrition with novel exclusion diets) has been shown superior in terms of achieving steroid-free remission, normal Creactive protein (CRP) remission, and mucosal healing in prospective and retrospective studies [8-12]. Although Scarpato et al. did not use propensity-score matching, they did show that their historical cohorts of EEN- vs steroid-treated patients did not differ for several features typically included in propensity-score matching. 
In their study, normal CRP was achieved significantly more often using EEN. Consistent with previous literature, normalization of calprotectin is achieved in a minority of patients using EEN or steroids: the composite outcome of normal Pediatric Crohn's Disease Activity Index (PCDAI) and calprotectin $<100$ was achieved in only a small subgroup for both treatments (14\% vs 5\%). This cohort was recruited before the previous 2014 European pediatric IBD guidelines were published, and these children were therefore not routinely started during induction treatment on an immunomodulator for maintenance $[4$, 13].

The low rate of steroid dependence and improvement of height $\mathrm{z}$-scores for both steroid- and EEN-exposed cohorts suggest an adequate escalation of immune suppression to avoid repeated and prolonged steroid treatment ( $84 \%$ by year 2 in the steroid treatment group vs $51 \%$ in EEN-induction group, $p=0.02$ ) This is in keeping with prospective pediatric evidence for the contribution of immunomodulators which is only available for reducing steroid exposure [1]. Scarpato et al. also show that after longer follow-up, there is no difference in the subgroups requiring treatment escalation towards anti-tumor necrosis factor (anti-TNF) in the children diagnosed in the era 2003-2013. In this retrospective study, the confounders of physician and family preference based on initial presentation, response, and tolerance of induction and maintenance strategies make the interpretation of longitudinal use of immune suppression and disease activity at later timepoints troublesome.

Consistent with previous reports, the subgroup of patients who achieve long-term clinical remission after a single course of nutrition without additional immunomodulation merits consideration [14]. Reducing exposure for this sizeable subgroup to immune suppression will become an essential topic for future study given the emergence of novel oral diet alternatives to EEN $[11,15]$. The Crohn's Disease Exclusion Diet (CDED) study recently showed that sustained exposure to diet therapy beyond achieving clinical remission at week 6 reduces early relapse (and rise in calprotectin) as occurs in up to $50 \%$ of EEN-treated patients $[15,16]$. Studies are ongoing to assess whether sustained dietary therapy beyond 12 weeks continues to be of benefit in the maintenance of remission.

Jongsma et al. report on a retrospective study of 215 children treated with infliximab between 2004 and 2019 in centers in Europe and Canada and provide compelling data that younger patients (IBD $<10$ years) are not achieving adequate induction dosing with current recommendations which were based on adult index studies [1, 5]. At the start of maintenance treatment, $72 \%$ of patients $<10$ years had trough levels below the therapeutic range $(<5.4 \mu \mathrm{g} / \mathrm{mL})$. The authors showed that these low trough doses were associated with a higher chance to develop antibodies to infliximab (ATI), which was reduced by co-immunomodulators. The trough levels themselves were not associated with age or co-immunomodulation, suggesting that optimized dosing for patients with higher clearance is achievable and recommendable [1]. Toxicity of higher trough levels has not been shown to date, whereas higher trough levels are associated with improved mucosal healing and outcomes of perianal disease $[17,18]$.

Younger patients who were able to continue on treatment for 1 year had a higher dose requirement per interval. At 2 years, the duration of response to infliximab was not significantly different between older and younger patients but still disappointingly low $(53-58 \%)$ given the evidence base, and experience with anti-TNF in pediatric IBD is still considerably better than for newer biologics [1]. These findings urge us to carefully consider assumptions regarding pharmacokinetics (i.e., not enough drug) vs pharmacodynamics (i.e., not mainly TNF-driven inflammation) when we label young IBD patients as "primary non-responders" [19]. Achieving adequate exposure to anti-TNF is complex, and clearance prediction based on the inflammatory burden, serum albumin levels, concomitant immunomodulators, and presence of ATI has already yielded pharmacokinetic "dashboards" which will require validation studies to guide dosing soon $[17,20,21]$.

The delay in the approval of new molecules for pediatric IBD - with more than 5 years between approval of biologics in adults to approval for use in children with IBD as a rule, not the exception - and safety concerns about increased immune suppression with infectious, oncologic, or hematologic side effects have triggered pediatric gastroenterologists to consider novel combinations of diet and anti-TNF therapy $[2,11,22$, 23]. Several studies have illustrated that partial EN can improve anti-TNF longevity as well as response to treatment escalation if standard dosing is insufficient in adult $\mathrm{CD}[24,25]$.

Considering proper treatment exposure to diet, steroids and anti-TNF during induction and maintenance may help us to avoid getting fooled into underestimating risks associated with inadequate treatment and too quickly abandoning therapeutic options with more favorable risk profiles.

\section{References}

1. van Rheenen PF, Aloi M, Assa A, Bronsky J, Escher JC, Fagerberg UL, Gasparetto M, Gerasimidis K, Griffiths A, Henderson P, Koletzko S, Kolho K-L, Levine A, van Limbergen J, Martin de Carpi FJ, Navas-López VM, Oliva S, de Ridder L, Russell RK, Shouval D, Spinelli A, Turner D, Wilson D, Wine E, Ruemmele FM (2020) The medical management of paediatric Crohn's disease: an ECCO-ESPGHAN Guideline update. J Crohn's Colitis. https:// doi.org/10.1093/ecco-jcc/jjaa161

2. Turner D, Griffiths AM, Wilson D, Mould DR, Baldassano RN, Russell RK, Dubinsky M, Heyman MB, de Ridder L, Hyams J, Martin de Carpi J, Conklin L, Faubion WA, Koletzko S, 
Bousvaros A, Ruemmele FM (2020) Designing clinical trials in paediatric inflammatory bowel diseases: a PIBDnet commentary. Gut 69(1):32-41. https://doi.org/10.1136/gutjnl-2018-317987

3. Turner D, Koletzko S, Griffiths AM, Hyams J, Dubinsky M, de Ridder L, Escher J, Lionetti P, Cucchiara S, Lentze MJ, Koletzko B, van Rheenen P, Russell RK, Mack D, Veereman G, Vermeire S, Ruemmele F (2016) Use of placebo in pediatric inflammatory bowel diseases: a position paper from ESPGHAN, ECCO, PIBDnet, and the Canadian Children IBD Network. J Pediatr Gastroenterol Nutr 62(1):183-187. https://doi.org/10.1097/mpg. 0000000000001024

4. Scarpato E, Strisciuglio C, Martinelli M, Russo M, Cenni S, Casertano M, Serra MR, Staiano A, Miele E (2020) Exclusive enteral nutrition effect on the clinical course of pediatric Crohn's disease: a single center experience. Eur J Pediatr. https://doi.org/10. 1007/s00431-020-03753-x

5. Jongsma MME, Winter DA, Huynh HQ et al (2020) Infliximab in young paediatric IBD patients: it is all about the dosing. Eur J Pediatr. https://doi.org/10.1007/s00431-020-03750-0

6. George J, Singh S, Dulai PS, Ma C, Nguyen T, Feagan BG, Sandborn WJ, Jairath V (2020) Corticosteroid-free remission vs overall remission in clinical trials of moderate-severe ulcerative colitis and Crohn's disease. Inflamm Bowel Dis 26(4):515-523. https://doi.org/10.1093/ibd/izz193

7. Krishnakumar C, Ballengee CR, Liu C, Kim MO, Baker SS, Baldassano RN, Cohen SA, Crandall WV, Denson LA, Dubinsky MC, Evans J, Gokhale R, Griffiths A, Guthery SL, Oliva-Hemker M, Heyman MB, Keljo D, Kellermayer R, Leleiko NS, Mack DR, Markowitz JF, Moulton DE, Noe JD, Otley AR, Patel AS, Pfefferkorn M, Rabizadeh S, Rosh JR, Snapper S, Walters TD, Ziring D, Mondal K, Kappelman MD, Hyams JS, Kugathasan S (2019) Variation in care in the management of children with Crohn's disease: data from a multicenter inception cohort study. Inflamm Bowel Dis 25(7):1208-1217. https://doi.org/10.1093/ ibd/izy363

8. Cohen-Dolev N, Sladek M, Hussey S, Turner D, Veres G, Koletzko S, Martin de Carpi J, Staiano A, Shaoul R, Lionetti P, Amil Dias J, Paerregaard A, Nuti F, Pfeffer Gik T, Ziv-Baran T, Ben Avraham Shulman S, Sarbagili Shabat C, Sigall Boneh R, Russell RK, Levine A (2018) Differences in outcomes over time with exclusive enteral nutrition compared with steroids in children with mild to moderate Crohn's disease: results from the GROWTH CD Study. J Crohns Colitis 12(3):306-312. https://doi.org/10.1093/ecco-jcc/ jjx 150

9. Pigneur B, Lepage P, Mondot S, Schmitz J, Goulet O, Dore J, Ruemmele FM (2018) Mucosal healing and bacterial composition in response to enteral nutrition versus steroid based induction therapy - a randomized prospective clinical trial in children with Crohn's disease. J Crohns Colitis 13:846-855. https://doi.org/10. 1093/ecco-jcc/jjy207

10. Yu Y, Chen KC, Chen J (2019) Exclusive enteral nutrition versus corticosteroids for treatment of pediatric Crohn's disease: a metaanalysis. World J Pediatr 15(1):26-36. https://doi.org/10.1007/ s12519-018-0204-0

11. Urlep D, Benedik E, Brecelj J, Orel R (2020) Partial enteral nutrition induces clinical and endoscopic remission in active pediatric Crohn's disease: results of a prospective cohort study. Eur J Pediatr 179(3):431-438. https://doi.org/10.1007/s00431-019-03520-7

12. Sigall Boneh RVLJ, Wine E, Assa A, Shaoul R, Milman P, Cohen S, Kori M, Peleg S, On A, Shamaly H, Abramas L, Levine A (2020) Dietary therapies induce rapid response and remission in active paediatric Crohn's disease Clin Gastroenterol Hepatol. https://doi. org/10.1016/j.cgh.2020.04.006)

13. Ruemmele FM, Veres G, Kolho KL, Griffiths A, Levine A, Escher JC, Amil Dias J, Barabino A, Braegger CP, Bronsky J, Buderus S, Martin-de-Carpi J, De Ridder L, Fagerberg UL, Hugot JP, Kierkus
J, Kolacek S, Koletzko S, Lionetti P, Miele E, Navas Lopez VM, Paerregaard A, Russell RK, Serban DE, Shaoul R, Van Rheenen P, Veereman G, Weiss B, Wilson D, Dignass A, Eliakim A, Winter H, Turner D (2014) Consensus guidelines of ECCO/ESPGHAN on the medical management of pediatric Crohn's disease. J Crohns Colitis 8(10):1179-1207. https://doi.org/10.1016/j.crohns.2014.04.005

14. Connors J, Basseri S, Grant A, Giffin N, Mahdi G, Noble A, Rashid M, Otley A, Van Limbergen J (2017) Exclusive enteral nutrition therapy in paediatric Crohn's disease results in long-term avoidance of corticosteroids: results of a propensity-score matched cohort analysis. J Crohns Colitis 11(9):1063-1070. https://doi.org/10. 1093/ecco-jcc/jjx060

15. Levine A, Wine E, Assa A, Sigall Boneh R, Shaoul R, Kori M, Cohen S, Peleg S, Shamaly H, On A, Millman P, Abramas L, ZivBaran T, Grant S, Abitbol G, Dunn KA, Bielawski JP, Van Limbergen J (2019) Crohn's disease exclusion diet plus partial enteral nutrition induces sustained remission in a randomized controlled trial. Gastroenterology 157 (2):440-450.e448. https://doi. org/10.1053/j.gastro.2019.04.021

16. Logan M, Clark CM, Ijaz UZ, Gervais L, Duncan H, Garrick V, Curtis L, Buchanan E, Cardigan T, Armstrong L, Delahunty C, Flynn DM, Barclay AR, Tayler R, McDonald E, Milling S, Hansen RK, Gerasimidis K, Russell RK (2019) The reduction of faecal calprotectin during exclusive enteral nutrition is lost rapidly after food re-introduction. Aliment Pharmacol Ther 50:664-674. https://doi.org/10.1111/apt.15425

17. Rinawi F, Ricciuto A, Church PC, Frost K, Crowley E, Walters TD, Griffiths AM (2020) Association of early postinduction adalimumab exposure with subsequent clinical and biomarker remission in children with Crohn's disease. Inflamm Bowel Dis. https://doi.org/10.1093/ibd/izaa247

18. El-Matary W, Walters TD, Huynh HQ, deBruyn J, Mack DR, Jacobson K, Sherlock ME, Church P, Wine E, Carroll MW, Benchimol EI, Lawrence S, Griffiths AM (2019) Higher postinduction infliximab serum trough levels are associated with healing of fistulizing perianal Crohn's disease in children. Inflamm Bowel Dis 25(1):150-155. https://doi.org/10.1093/ibd/ izy 217

19. Sparrow MP, Papamichael K, Ward MG, Riviere P, Laharie D, Paul S, Roblin X (2020) Therapeutic drug monitoring of biologics during induction to prevent primary non-response. J Crohns Colitis 14(4):542-556. https://doi.org/10.1093/ecco-jcc/jjz162

20. Colman RJ, Tsai YT, Jackson K, Boyle BM, Noe JD, Hyams JS, D'Haens G, van Limbergen J, Rosen MJ, Denson LA, Minar P (2020) Achieving target infliximab drug concentrations improves blood and fecal neutrophil biomarkers in Crohn's disease. Inflamm Bowel Dis. https://doi.org/10.1093/ibd/izaa241

21. Bauman LE, Xiong Y, Mizuno T, Minar P, Fukuda T, Dong M, Rosen MJ, Vinks AA (2020) Improved population pharmacokinetic model for predicting optimized infliximab exposure in pediatric inflammatory bowel disease. Inflamm Bowel Dis 26(3):429-439. https://doi.org/10.1093/ibd/izz143

22. Sigall Boneh R, Sarbagili Shabat C, Yanai H, Chermesh I, Ben Avraham S, Boaz M, Levine A (2017) Dietary therapy with the Crohn's Disease exclusion diet is a successful strategy for induction of remission in children and adults failing biological therapy. J Crohns Colitis 11(10):1205-1212. https://doi.org/10.1093/eccojcc/jjx071

23. Levine A, El-Matary W, Van Limbergen J (2020) A case-based approach to new directions in dietary therapy of Crohn's disease: food for thought. Nutrients 12(3). https://doi.org/10.3390/ nu12030880

24. Hirai F, Takeda T, Takada Y, Kishi M, Beppu T, Takatsu N, Miyaoka M, Hisabe T, Yao K, Ueki T (2020) Efficacy of enteral nutrition in patients with Crohn's disease on maintenance anti- 
TNF-alpha antibody therapy: a meta-analysis. J Gastroenterol 55(2):133-141. https://doi.org/10.1007/s00535-019-01634-1

25. Hisamatsu T, Kunisaki R, Nakamura S, Tsujikawa T, Hirai F, Nakase H, Watanabe K, Yokoyama K, Nagahori M, Kanai T, Naganuma M, Michimae H, Andoh A, Yamada A, Yokoyama T, Kamata N, Tanaka S, Suzuki Y, Hibi T, Watanabe M, group CT (2018) Effect of elemental diet combined with infliximab dose escalation in patients with Crohn's disease with loss of response to infliximab: CERISIER trial. Intest Res 16(3):494-498. https:// doi.org/10.5217/ir.2018.16.3.494

Publisher's note Springer Nature remains neutral with regard to jurisdictional claims in published maps and institutional affiliations. 